time, the development strategy should be based on the enterprise's susceptibility to innovations and readiness to implement them.

It has been proved requires special approaches to the perception of problems and their assessment. Since the main feature of the environment of innovative enterprises is market and social uncertainty, there is a need to form specific theoretical and practical methods for ensuring the implementation of innovative projects with a focus on minimizing risks.

Research confirms that an innovative project is proposed to be understood as a system of interrelated tasks, is a complex of research, development, production, technological, organizational, financial, commercial and other events, appropriately organized, drawn up with a set of design documentation for estimate calculations and efficiency calculations, which provide an effective solution to a specific scientific and technical problem of an innovative nature in for a certain time.

It has been established that an innovative project is based on the concept of its life cycle, which proceeds from the fact that an innovative project is a process that continues from the moment the strategy of a new product is developed until the moment of liquidation. It is advisable to distinguish three stages of the life cycle - the formation, implementation and completion of an innovative project.

That the management of an innovative project is an indispensable element of building a competitive strategy for survival in new markets during a period of rapid scientific and technological development and. activity

Key words: innovation, management, project, innovative product, innovative

DOI 10.31395/2415-8240-2021-98-2-211-221

\title{
ANALYSIS OF FINANCIAL SUPPORT OF GENERAL SECONDARY EDUCATION INSTITUTIONS IN THE CONDITIONS OFREORGANIZATION
}

\author{
L. V. LUKASHENKO, graduate student \\ O. A. DEMYANYSHYNA, Candidate of Economic Sciences \\ Pavlo Tychyna Uman State Pedagogical University
}

У статті проаналізовані особливості фінансування закладів загальної середньої освіти в умовах децентралізації та адміністративної реформи. Подано характеристику джерел фінансування. Досліджено сучасний стан фінансування загальної середньої освіти в Україні. Результати дослідження засвідчують конструктивність та доцільність реформи децентралізаиії.

Ключові слова: заклади загальної середньої освіти, фінансування, бюджет, фінансові ресурси, реформи, освітня галузь.

At the present stage of systemic social change and reform of general secondary education, much attention is paid to scientists, research workers and practitioners to the optimal financial support of education, because investment in education is 
investment in human and social capital in the future of our country. Provided good governance and with proper management, financial investment in education will promote Ukraine's economic growth and social development, ensure socio-economic growth, and increase the well-being of Ukrainians and the competitiveness of our country.

Problem statement. One of the main problems of the education sector is the imperfection of the funding system, which is due to the presence of objective and subjective factors: lack of concept of well-thought-out reforms, inconsistency of actions at the level of public administration, inconsistent policy, economic crisis, military action in the east and etc. Low social status and wages demoralize teachers. Teachers do not have a real motivation for personal and professional growth.

Due to chronic underfunding of the general secondary education sector, not all students have access to quality education guaranteed by the state, especially in rural areas, where one teacher teaches several subjects. The school reproduces poverty: children from low-income families are less likely to receive a quality education and climb the social ladder, which is why there is an urgent need to reform general secondary education.

The relevance of the research topic. The financing of the general secondary education system has become promising in the context of European integration and global challenges of globalization. The relevance of this topic lies in the need to study the state of financing of general secondary education in the context of reorganization.

Various fundamental aspects of the implementation of financial policy in the field of education have been the subject of active discussion and systematic research by scientists and practitioners, J. Becker, K. Wayne, R. Dave, W. Draskowitz, A. Correa, P. Lengran, R. Musgrave, R. Neva, M. Palacius, T. Zoran and others.

Some aspects of this issue are devoted to the works of domestic scientists, in particular T. Bogolib, V. Burova, V. Vlasyuk, O. Grigorskaya, O. Grishnova, O. Dlugopolsky, L. Kalinina, I. Kalenyuk, L. Kozarezenko ， V. Malyshko, G. Matveeva, V. Meleshko, I. Osadchy, O. Lokshina, Y. Petrushenko, I. Radionova, V. Satsyk, V. Tropina, V. Usyk, Y. Kharchuk, G. Chekalovska, L. Shalaeva, M. Shevtsova, L. Shevchenko, A. Shevchuk and others.

The purpose of the article is to study the peculiarities of the financing of general secondary education institutions in the conditions of reorganization and to determine the ways of economic stimulation of their activity based on the principle «money follows the child».

The theoretical and methodological basis of the study were regulations, legislation, financial reports, scientific papers of domestic and foreign scholars, and practitioners who studied the fundamental aspects of financial policy in education. The study used: statistical, graphical, statistical and economic methods, methods of comparison, analysis, explanation.

The subject of the study is the sources of funding for general secondary education in Ukraine and identified areas for their optimization.

The task of the article is to analyze the dynamics of financing of general secondary education institutions in Ukraine in recent years, and to compare the initial economic conditions at the beginning of the reform in Ukraine and Poland; 
substantiate effective approaches to public funding of education using the positive experience of Poland [1].

Research results. Unfortunately, there is very little analytical research on the reorganization of general secondary education and aspects of its financing, as the reform has started relatively recently, so this topic is extremely relevant now.

The order of the Cabinet of Ministers of Ukraine of December 14, 2016, № 988 «On approval of the Concept of implementation of state policy in the field of reforming general secondary education» New Ukrainian School «until 2029», outlined that the main problem that prompted the reorganization of general secondary education was a significant deterioration in the quality of general secondary education during 1992-2016. The consequence of this is several factors, the main of which are: reduction of funding; reduction of teachers' salaries; unsatisfactory logistics of schools; bureaucratization of the education management system; outdated content of education and teaching methods [9].

Analyzing the labor market, it is safe to say that the most successful are professionals who know how to work in a team, think critically, learn throughout life and constantly improve their professional skills, set goals and achieve them, communicate in a multicultural environment and have the skills to find information. There is no person in the world who can confidently say: «I know everything!», Because even in the narrowest field it is impossible to know everything, because the world is constantly changing due to scientific and technological progress, technological improvements, etc. Therefore, starting from primary school age, the task for a general secondary school teacher is not just to transfer knowledge to students, but to teach them to think, analyze, select from a huge amount of information the most necessary and apply the acquired knowledge in practice. Unfortunately, the modern Ukrainian school does not provide the necessary skills, so there is a need to reorganize general secondary education.

Developed countries in Europe, the United States, Canada, and Japan have already reformed their education and are now successfully applying the concepts of individual education programs instead of traditional lessons - comprehensive research of topics, acquisition of skills of critical and creative thinking, acquisition of lifelong knowledge anywhere, anytime, in any form.

Ukraine is just on this path, and the reform of secondary education is a reform focused on training a school graduate who is fully developed, capable of critical thinking, a holistic personality, a patriot with an active position, an innovator who can change the world and learn throughout life.

The ideology of the reform was the concept of «New Ukrainian School», which is based on: «Concept of Education Development of Ukraine for the period 2015-2025», prepared by the Strategic Advisory Group «Education» within the joint project of the International Renaissance Foundation and Charitable Foundation «Institute for the Development of Education», as well as the «Concept of Secondary School of Ukraine» of the National Academy of Pedagogical Sciences of Ukraine, «Vision of the New Ukrainian School», prepared by the community of responsible teachers ED Camp Ukraine. The developers of the updated program focused on 
European recommendations approved by the European Parliament and the Council of the EU [6].

In particular, the Recommendations of the European Parliament and the Council of the EU identify eight basic competencies that should be formed through education, necessary for each person for personal formation and development, active citizenship, social inclusion, and employment: communication in the native language (oral and written); communication in foreign languages; mathematical competencies and basic competencies in natural sciences and technologies; digital competencies; ability to learn; social and civic competences; initiative and entrepreneurial skills; general cultural literacy and the ability to express oneself [10].

Analyzing the successful experience of reforms in the administrative-territorial system and local self-government of developed countries, most Ukrainian reformers agreed that the experience of neighboring Poland can be considered the closest to Ukrainian realities, and the starting conditions for reforms in Ukraine and Poland do not differ significantly.

The initial economic conditions at the beginning of the reform in Ukraine and Poland are shown in Table. 1.

Table 1. Starting economic conditions at the beginning of the reform in Ukraine and Poland

\begin{tabular}{|l|c|c|c|c|}
\hline Years & $\begin{array}{c}\text { GDP growth in } \\
\%\end{array}$ & Inflation in $\%$ & $\begin{array}{c}\text { The amount of } \\
\text { public debt in } \\
\% \text { of GDP }\end{array}$ & $\begin{array}{c}\text { GDP per capita } \\
\text { (USD) }\end{array}$ \\
\hline \multicolumn{5}{|c|}{ Poland } \\
\hline 1989 & 3.8 & 251.1 & 0.0 & 1770 \\
\hline 1990 & -7.2 & 585.8 & 0.0 & 1626 \\
\hline 1991 & -7.0 & 70.3 & 0.0 & 2102 \\
\hline 1997 & 7.1 & 14.9 & 42.9 & 4059 \\
\hline 1998 & 5.0 & 11.8 & 38.9 & 4444 \\
\hline 1999 & 4.5 & 7.3 & 39.6 & 4336 \\
\hline \multicolumn{5}{|c|}{ Ukraine } \\
\hline 2013 & 0.0 & -0.5 & 40.3 & 4030.3 \\
\hline 2014 & -6.6 & 12.5 & 70.3 & 3014.6 \\
\hline 2015 & -9.8 & 49.3 & 94.9 & 2115.4 \\
\hline 2016 & 2.4 & 12.4 & 81.0 & 2185.9 \\
\hline 2017 & 2.5 & 13.7 & 71.8 & 2641.4 \\
\hline 2018 & 3.3 & 9.8 & 60.9 & 3095.1 \\
\hline 2019 & 3.2 & 4.1 & 50.3 & 3707 \\
\hline 2020 & 3.8 & 5.0 & 57.6 & 3425 \\
\hline
\end{tabular}

After analyzing the data in Table 1, we can conclude that the first stage of decentralization reform in Poland took place in difficult economic conditions, as in Ukraine at the present stage (falling GDP, inflation). The only difference is that the first stage of reform in Poland took place in the absence of debt pressure on the 
country's budget, and the second stage of reforms (1998-1999) took place in conditions of economic growth [4].

After the first four-year phase of reforms, Poland ranked third after Finland and Singapore in terms of scientific literacy among 15-year-olds, ahead of the British and Americans. That is why Ukrainian reformers, thinking over the concept of reforms, focused on successful, innovative models from the world experience, in particular the modern Polish innovative educational system.

However, the content of education is extremely country specific. You cannot take as a tracing paper the experience of Poland, Finland, Singapore or any other, you need to build your concept, taking into account the needs of the labor market, economic development, mentality, as M. Gorky wrote «Learn from everyone, do not imitate anyone».

Today's reality requires a person to continuously improve their professional skills. Therefore, in order for education in Ukraine to be not only at a high level, but also to become interesting for students, it is necessary to build such an education system that will allow to train a highly qualified, creative, enterprising specialist; a person who is able to think critically, apply the acquired knowledge in practice, solve problems, make decisions, assess risks, constructively manage emotions, cooperate in a team.

The key vector of reform of general middle school was become by equipping with modern amenities of financing of educational sphere, in fact one of basic terms of providing of high-quality education there is the proper financing. For today the source of the financial providing of sphere of education is state assignation due to a money state and local budgets and other sourcing not forbidden by a legislation.

In Fig.1. presents the dynamics of expenditures of the consolidated budget of Ukraine for education for the period from 2014 to 2019 according to the reports of the State Treasury Service of Ukraine.

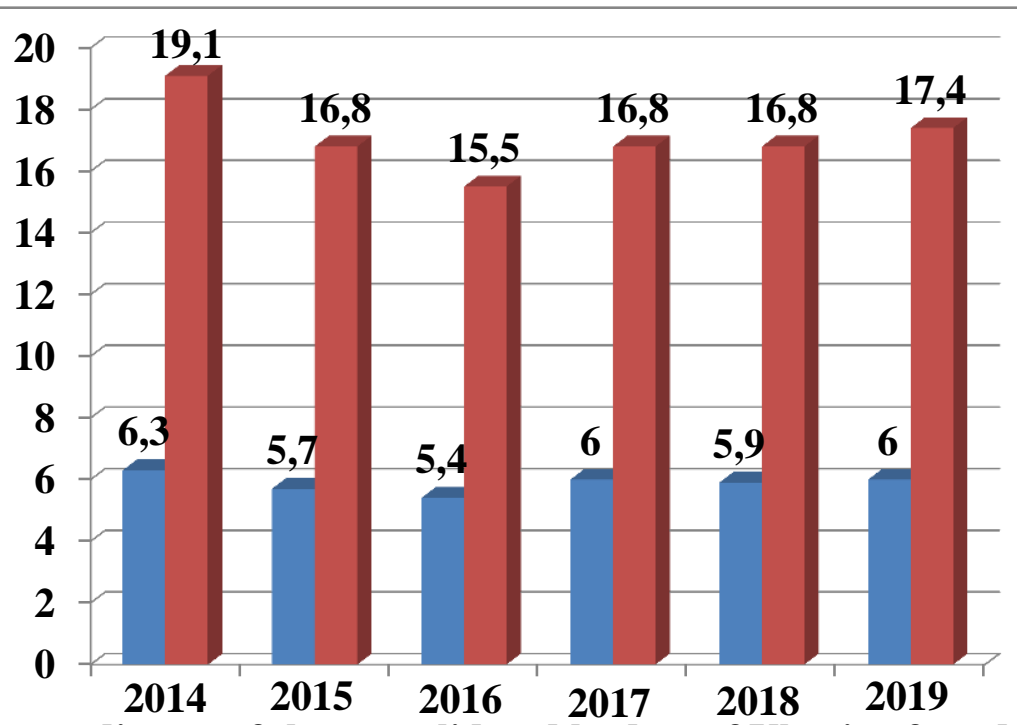

The ratio of expenditures of the consolidated budget of Ukraine for education to GDP

Fig. 1. Expenditures of the consolidated budget of Ukraine for education in 2014-2019

Built according to the State Treasury Service of Ukraine. 
Analyzing the figure, we see that during 2014-2016, the ratio of expenditures of the consolidated budget of Ukraine for education to GDP decreased from $6.3 \%$ to $5.4 \%$, and since 2017 . The situation improved and education expenditures increased significantly between 2017 and 2019.

Without regard to the considerable financing of defensive sphere it is caused military operations, the state finds possibilities to finance education, however on education to GDP unfortunately the percent of charges of the erected budget so far did not attain $7 \%$, as it is fastened in the article of a 78 Law of Ukraine "About education».

In 2019, expenditures on education amounted to UAH 239,437 million $(6.0 \%$ of GDP, or $17.4 \%$ of total consolidated expenditures) budget of Ukraine). For comparison: in 2018, this amount amounted to UAH 210,679 million (5.9\% of GDP, or $16.8 \%$ of the total expenditures of the consolidated budget of Ukraine). That is, even in times of crisis, the Government of Ukraine has provided financial support to the education sector at the level necessary to continue its reform. In 2020 on the necessities of education the budgetary financing was foreseen in size of UAH 267 404,6 million, that on UAH 27 967,7 million. (10,5\%) more than in 2019.

In general, $16.6 \%$ of the total expenditures of the consolidated budget of Ukraine were planned for education. Of this amount, UAH 229,244.8 million $(85.7 \%)$ was to be financed from the general fund and UAH 38,159.8 million $(14.3 \%)$ from the special fund [1].

It is estimated that the ratio of education expenditures in the consolidated budget of Ukraine to GDP in 2020 also did not reach $7 \%$. Regarding the distribution by sources of funding, $49 \%$ of funds were allocated from local budgets, $21 \%$ - from the state budget and $30 \%$ were intergovernmental transfers to the education subvention (see Fig. 2).

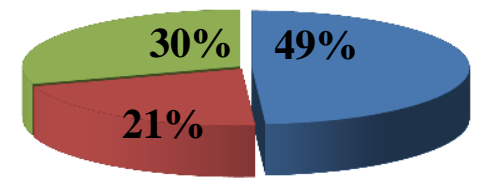

口Education subvention $49 \%$

$\square$ Education expenditures from the local budgets (for the wine of the eucation subvention $21 \%$

$\square$ Education expenditures from the state budget $30 \%$

\section{Fig. 2. Distribution of funding for education by sources in $2020, \%$}

Built according to the State Treasury Service of Ukraine

However, due to the need to release financial resources for the Fund for Combating Acute Respiratory Disease COVID-19 caused by coronavirus SARS$\mathrm{CoV}-2$, and its consequences, the Verkhovna Rada Committee on Budget together with the Ministry of Finance of Ukraine developed a draft Law of Ukraine «On 
Amendments to the Law of Ukraine», « On the State Budget for 2020» № 3279-d of April 11, 2020. This bill proposed amendments to the Law of Ukraine «On the State Budget of Ukraine for 2020», which affected the financial capacity of local governments and, in particular, the development of education.

April 13, 2020, the draft Law of Ukraine «On Amendments» to the Law of Ukraine «On the State Budget for 2020» (№ 3279-d of 11.04.2020) was adopted by 252 votes of the People's Deputies of Ukraine.

Due to the adopted law, the expenditures of the Ministry of Education and Science were reduced from UAH 131.6 billion to UAH 126.6 billion.

On December 15, 2020, the Verkhovna Rada adopted the Law of Ukraine «On the State Budget of Ukraine for 2021», in which the Ministry of Education and Science of Ukraine provides for expenditures amounting to UAH 139.5 billion, which is UAH 26.6 billion UAH more than in 2020 . These are mainly funds for an increase in wages, which increased by $20 \%$ from January 1, 2021 and another increase from 8 December 2021 by $8.4 \%$ is planned.

Of this amount, national expenditures (subventions) amount to UAH 103.7 billion, this is UAH 20.1 billion more than in 2020. Subvention for general secondary education «New Ukrainian School» in 2021 will amount to UAH 1.42 billion. (UAH 0.4 billion - advanced training of teachers UAH 1.02 billion purchase of teaching aids and equipment); subvention for the implementation of the program «Able school for better results» - UAH 1.0 billion [11].

There is also a new subvention in the amount of UAH 1.0 billion for measures aimed at combating acute respiratory disease COVID-19 and its consequences during the educational process in general secondary education [11].

Conclusions. Financing education is an important issue on the agenda of any country, especially in a budget deficit, but given the strategic importance of education in Ukraine, we believe it is necessary to increase government spending to support the education sector, including general secondary education, which is in a state of reform. Recently, there have been increasing discussions about the effectiveness of the financial mechanism in education, identifying the strengths and weaknesses of national funding systems in various countries, including Ukraine.

Analyzing statistics on education funding in Ukraine and reports State Treasury Service of Ukraine on-budget execution, we conclude that despite the complexity of the socio-economic situation and the long-armed conflict in the Donbas, there is a gradual increase in education spending, which amounted to about 6\% of GDP.

In our opinion, the results of the study testify to the constructiveness and expediency of decentralization reform. The study of the state of financial support of education proves that the improvement of material and technical base, decent wages of teachers allow to put the student in the spotlight and create conditions for its harmonious development, which is the foundation for creating competitive human capital in the national economic system.

\section{Література}

1. Аналітичний центр CEDOS. URL: https://www. cedos.org.ua/ (дата звернення: 16.02.2021). 
2. Беззуб I.. «Реформа середньої освіти в Україні» URL: http://nbuviap.gov.ua/

3. Боголіб Т. Фінансове забезпечення освітньої галузі України: існуючі проблеми та перспективи їх вирішення. Економіст. 2015. № 8. С. 1-6.

4. Виконання Державного бюджету/Державна казначейська служба України URL: http://www.treasury.gov.ua/main/uk/doccatalog/ list?currDir=146477 (дата звернення 26.03.21)

5. Гербст М., Герчиньский, Я. Децентралізація освіти у Польщі: досвід 25 років. Варшава: Інститут освітніх досліджень, 2015. 23 с.

6. Гриневич Л. Тенденції децентралізації управління базовою освітою в сучасній Польщі: Дисертація на здобуття наукового ступеня канд. пед. наук. Львів, 2004.

7. Державна служба статистики URL: http://www.ukrstat.gov.ua/(дата звернення 17.04.2021).

8. Інформаційно аналітичний збірник «Освіта в Україні: виклики та перспективи» URL: https://mon.gov.ua/ (дата звернення 03.05.2021).

9. Конституція України: офіц. текст. Київ: КМ, 2013. 96 с.

10. Концепція реалізації державної політики у сфері реформування загальної середньої освіти «Нова Українська школа» на період до 2029 року. Офіц.. текст. Київ: КМ, 2016.

11.Міністерство освіти і науки України URL: https://mon.gov.ua/ (дата звернення 15.04.2021).

12. Міністерство фінансів України URL: http://www.minfin.gov.ua/ (дата звернення 15.04.2021).

13. Національні рахунки освіти України у 2020 році : Статистичний збірник. Державна служба статистики України. URL: http://www.ukrstat. gov.ua/druk/publicat/kat_u/publosvita_u.htm (дата звернення 01.03.2021).

14. Про загальну середню освіту: Закон України від 13.05.1999 № 651XIV: за станом на 10.04.14. Верховна Рада України URL: http://zakon1.rada.gov.ua/laws/show/651-14 (дата звернення 25.04.2021).

15. Статистичні дані України. Розділ “Освіта”. Державна служба статистики України. URL: http://www.ukrstat.gov.ua/druk/publicat/kat_u/ publosvita_u.htm (дата звернення 23.04.2021).

16. Статистичні дані. Розділ "Видатки" URL: http:// cost.ua/budget/expenditure/ (дата звернення 26.03.2021).

\section{References}

1. Analytical center CEDOS. URL: https://www. cedos.org.ua/ (date of application: 16.02.2021).

2. Bezzub, I.: Secondary education reform in Ukraine

3. Bogolib, T. (2015) Financikal support of the educational sector of Ukraine, existing problems and prospekt for their solution. Economist, no. 8, pp. 1-6.

4. Execution of the state budget. The State Treasury Servise of Ukraine:http://www.treasury.gov.ua/main/uk/doccatalog/ list?currDir=146477 (of application: 26.03.21). 
5. Gerbst, M, Gerchunsky, Y. (2015). Decentralization of education in Poland 25 yearsof experience. $23 \mathrm{p}$.

6. Grynevich, L. (2004) Trends of decentralization of basic education management in modern Poland-Lviv. Dr. tech. sci. diss.

7. The state statistics of service: http://www.ukrstat.gov.ua/ (of application: 17.04.2021).

8. Information - analytical collection:The education in Ukraine challenges and prospects: https://mon.gov.ua/.

9. The Constitution of Ukraine official text. KM, (2013), $96 \mathrm{p.}$

10. The concept of implementation of state policy in the field of reforming general secondary education (2016): The new Ukrainian school official text. KM: Kyiv.

11. Ministry of Education and Science of Ukraine: https://mon.gov.ua/.

12. The Ministry of Finanse of Ukraine: http://www.minfin.gov.ua/.

13. National education accounts of Ukraine in 2020: Statistical collection: The State Statistics Service of Ukraine: http://www.ukrstat. gov.ua/druk/publicat/kat_u/publosvita_u.htm.

14. The law of Ukraine on general secondary education: The law of Ukraine. 13.05.1999 №651-XIV: http://zakon1.rada.gov.ua/laws/show/651-14.

15. ServiceofUkraine.Section the education. The State Statistics Service of Ukraine: http://www.ukrstat.gov.ua/druk/publicat/kat_u/publosvita_u.htm.

16. Statistics.Section «Expenses»: http:// cost.ua/budget/expenditure/.

\section{Аннотация}

Лукашенко Л. В., Дем'янишина О. А. Анализирование финансового обеспечения общеобразовательных заведений в условиях реорганизации

Предметом исследования являются источники финансирования заведений средней школь в Украине и определены направления их оптимизации.

Целью является исследование особенностей финансирования заведений средней школы в условиях реорганизации и определение путей экономического стимулирования их деятельности на основании принципа «деньги ходят за ребенком».

Методика исследования. Работа выполнена на основании статьи 53 Конституции Украины, нормативных актов, законодательных актов, финансовых отчетов, научных исследований отечественных и зарубежных ученых и практиков. Методы исследования: статистический, графический, статистико-экономический, методы сопоставления, анализа

Результаты исследования современного состояния финансирования заведений общеобразовательной школь свидетельствуют, что для решения проблем отрасли необходимо разработать иелосную систему мероприятий, которые будут направлены на обеспечение ее эфективного развития с учетом требований европейских стандартов. Проведенное исследование свидетельствует также об необходимости реформы децентрализации.

Область применения результатов исследования. В условиях 
децеентрализации и административного реформирования инвестирование в человеческий капитал становится ведущчим приоритетом, направленным на стратегические действия направленные на экономическое прочветание страны. Исследование современного состояния финансирования общеобразовательных заведений доказывает, что улучиение материальнотехнической базы, достойная заработная плата учителей дают возможность поставить ученика в центр внимания и создать условия для его гармонического развития, а это даст возможность для создания конкурентного человеческого капитала для наџиональной экономики. Для достижения мировых стандартов в области образования необходимо проводить реформирование, которое обеспечит эфффективную систему финансирования.

Выводы. Следовательно, дефицит бюджета на среднеобразовательную школу влияют на снижение качества и эффективность образовательных услуг. Особенную роль должна играть система управления и контроля над деятельностью бюджетных учреждений. Для улучшения положения в области финансирования образования необходимо формировать осуществление бюджетных расходов исходя из сочетания отечественного и мирового опьта, отчасти из опьта соседней Польши для этого необходимо проведение реформыл образования.

Ключевые слова: общеобразовательные заведения, финансирование, бюджет, финансовые ресурсы, реформы, сфера образования.

\section{Annotation}

\section{Lukashenko L. V., Demianyshyna O. A.}

Analysis of financial support of educational institutions in the conditions of reorganization

The subject of the research is the sources of financing of secondary schools in Ukraine and the directions of their optimization are determined.

The aim is to study the features of financing of secondary schools in the context of reorganization and to determine ways of economic stimulation of their activities on the basis of the principle "money follows the child".

Research methodology. The work was carried out on the basis of Article 53 of the Constitution of Ukraine, normative acts, legislative acts, financial reports, scientific research of domestic and foreign scientists and practitioners. Research methods: statistical, graphic, statistical and economic, methods of comparison, analysis.

The results of the study of the current state of financing of secondary school institutions indicate that in order to solve the problems of the industry, it is necessary to develop a coherent system of measures that will be aimed at ensuring its effective development, taking into account the requirements of European standards. The study also indicates the need for a decentralization reform

Scope of the study results. In the context of decentralization and administrative reform, investment in human capital is becoming a leading priority aimed at strategic actions aimed at the economic prosperity of the country. The study of the current state of financing of general education institutions proves that 
improving the material and technical base, decent wages of teachers make it possible to put the student in the center of attention and create conditions for his harmonious development, and this will provide an opportunity to create competitive human capital for the national economy. To achieve world standards in the field of education, it is necessary to carry out reforms that will provide an effective system of financing.

Conclusions. Consequently, the budget deficit for secondary schools affects the decline in the quality and efficiency of educational services. The system of management and control over the activities of budgetary institutions should play a special role. To improve the situation in the field of education financing, it is necessary to form the implementation of budgetary expenditures based on a combination of domestic and international experience, partly from the experience of neighboring Poland, for this it is necessary to carry out an education reform.

Key words: educational institutions, financing, budget, financial resources, reforms, education.

\section{СУЧАСНI ТЕОРІЇ ЕКОНОМІЧНОГО РОЗВИТКУ: СОЦІАЛЬНІ АСПЕКТИ}
А. П. БУРЛЯЙ, доктор економічних наук
В. С. КОСТЮК, кандидат економічних наук
Л. В. СМОЛІй, кандидат економічних наук
А. А. ОСІПОВА, кандидат економічних наук
Уманський національний університет садівництва

У статті досліджено сучасні теорії економічного розвитку в контексті соціальних аспектів. Визначено їхню сутність та еволючію моделей економічного розвитку згідно з конщепџіями добробуту. Встановлено, щчо обов'язковою умовою успішного розвитку національної економічної системи $\epsilon$ забезпечення пріоритетності людини, освіти, охорони здоров'я, захист навколишнього середовища, які, в свою чергу, стимулюють значний економічний потенціал та багаторічне процвітання суспільства.

Ключові слова: сочіальні чинники економічного розвитку, теорії економічного розвитку, добробут, бідність, нерівність.

Постановка проблеми. Соціально-економічні процеси розвитку світового господарства в цілому та кожної національної економіки зазнають суттєвих змін на зламі XX-XXI ст., що закономірно позначається на розвитку економічної думки, появі сучасних економічних теорій, направлених на вивчення злободенних питань сьогодення. Як завжди актуальними залишаються фундаментальні проблеми економічної науки, насамперед, 